\title{
Taeniopteris novomundensis sp. nov. - "cycadophyte" foliage from the Carnian of Switzerland and Svalbard reconsidered: How to use Taeniopteris?
}

\section{Christian Pott ${ }^{1 *}$ \& Ahti Launis ${ }^{2}$}

With 5 figures.

\begin{abstract}
Recent findings of Taeniopteris-like foliage from the Carnian of Hopen, Svalbard, necessitated the re-evaluation of cycadophyte foliage from the Carnian flora of Neuewelt, Basel, Switzerland, revealing the illegitimate status of Taeniopteris angustifolia. The specimen from the Ladinian or Carnian (Lower Keuper) of Lower Franconia, Germany, on which the identification was based, was recently identified as the holotype of the marattialean fern Danaeopsis angustifolia, whereof Taeniopteris angustifolia is the basionym. This implies that the Neuewelt specimens lack any type and basionym, and a new species name is required. The specimens from Hopen as well as specimens elsewhere from Svalbard are identified as conspecific with the specimens from Neuewelt, and we here assign all specimens to Taeniopteris novomundensis sp. nov., which is thus known from the Carnian of Switzerland and Svalbard. Information on epidermal anatomy is not available, and the affinity of the species can, therefore, not be elucidated further, but is here interpreted as a cycadophyte. Several specimens from the Carnian of Franconia assigned to Taeniopteris angustifolia belong to a species different from Taeniopteris novomundensis, i.e. Taeniopteris kelberi. Earlier inclusion of some of the specimens now assigned to Taeniopteris novomundensis in Taeniopteris kelberi is unsupported. The typification and use of Taeniopteris are discussed in this framework.
\end{abstract}

Key words: Nilssoniopteris, Taeniopteris vittata, Taeniopteris angustifolia, Danaeopsis, Keuper, Lunz, Franconia, Bennettitales, Cycadales 


\section{Introduction}

The Carnian flora from Neuewelt close to Basel, Switzerland (Fig. 1A), comprises wellpreserved compression plant fossils and is, moreover, coeval with the excellently preserved flora from Lunz-am-See, Austria. The latter is currently being revised in detail (e.g. PotT 2007; PotT et al. 2007a, 2007b, 2008, 2010). Both floras share a high number of species, but there are a number of species, which occurred only in either flora. One of these species is a foliage type from Neuewelt attributed to Taeniopteris angustifolia, which, according to current perception, appears to be a common representative of Ladinian-Norian floras of the southern German Basin. The foliage is of unknown affinity and is mentioned in a number of older and recent publications (i.a. SCHENK 1864; SCHENK in SCHÖNLEIN 1865; Compter 1874, 1894, 1912; HeER 1877; LeUthardt 1904; KRÄUSEL \& SCHAARSCHMidT 1966; KelbeR \& HANSCH 1995; KELBER \& NITSCH 2005).

From Neuewelt, Taeniopteris angustifolia was first reported by HEER (1877), who based the identification of his specimens on an illustration of a specimen from the Ladinian or Carnian (Lower Keuper) of Lower Franconia, published by SCHENK (1864, pl. 2, fig. 5) as Taeniopteris angustifolia. The specimen of SCHENK (1864) shows a compound fern-like leaf and HEER (1877) interpreted the single leaves from Neuewelt as isolated pinnae of such a frond.

The specimen of SCHENK (1864), however, was recently identified as the holotype of the marattialean fern Danaeopsis angustifolia (KUSTATSCHER et al. 2012), whereof the name Taeniopteris angustifolia is consequently the basionym. The leaves from Neuewelt are, in contrast, not only completely different in their appearance, their anatomy (shape, outline, venation) from Danaeopsis angustifolia, but also more likely to interpret as single, entiremargined leaves than as leaflets of a compound leaf or frond, due to their symmetrical shape, their prominent petiole and the fact that they apparently are shed individually. Therefore, we regard the leaves from Neuewelt attributed to Taeniopteris angustifolia not conspecific with Danaeopsis angustifolia. This implies that all specimens, which were identified as Taeniopteris angustifolia based on HEER (1877) need reconsideration.

Recent findings of well-preserved identical leaves from Carnian strata on the islands of Hopen and Edgeøya, Svalbard (Fig. 1A), raised interest in this species and, in consequence of the study by KUSTATSCHER et al. (2012), necessitated the revision of Taeniopteris angustifolia sensu HEER (1877) and its taxonomic status. In the present study, we re- 
evaluated the original material from Neuewelt together with the new specimens from Hopen and Edgeøya. As no holotype is available and Taeniopteris angustifolia is the basionym for Danaeopsis angustifolia, a new species name with a new type is required.

\section{Material and methods}

The original material of Taeniopteris angustifolia from Neuewelt comprises eleven specimens (HeER 1877; KRÄUSEL \& SCHAARSCHMIDT 1966), whereof eight are still present in the paleontological collections of the Natural History Museum of Basel, Switzerland, and available under accession numbers NHMB B635-640, B641/2, B722/2; two additional specimens (B633 and B1376) were mentioned by KRÄUSEL \& SCHAARSCHMIDT (1966). From a recent geological excursion to Hopen (LAUNIS et al. 2014), three specimens yielding Taeniopteris leaves were obtained at Gåsskaret on Kollerfjellet. Those specimens are stored in the paleontological collections of the Natural History Museum, Oslo, Norway, under accession numbers PMO 227.556A, 227.561 and 227.573. Nineteen specimens from Kvalpynten on Edgeøya, yielding 20 leaves, were identified in the palaeobotanical collections of the Laboratory of Palaeobotany and Palynology (LPP), University Utrecht, The Netherlands (accession numbers $24210,24215,24216,24218,15$ specimens without number), on a recent visit of CP. In addition to these specimens, a few specimens from Kapp Lee on Edgeøya (Svalbard; Fig. 1A) and Kollerfjellet on Hopen have been considered, which have earlier been published by Vasilevskaya $(1972,1983)$ (cf. PotT 2012). These specimens are stored in the A. P. Karpinsky Russian Geological Research Institute VSEGEI, St. Petersburg, Russian Federation, under accession numbers 10979-24, 10979-25, 10979-52, 10979-65, 10979-71, 4/12163, 18/12163-20/12163 and were examined during a visit of CP in 2011.

The specimens from Neuewelt (Münchenstein) come from the Carnian Schilfsandstein Member of the Mergelkeuper Formation (SCHMASSMANN 1953; BITTERLI-BRUNNER 1987; JORDAN 2008); the specimens from Hopen and Edgeøya have been obtained from two beds within the lower part of the Carnian-Norian De Geerdalen Formation (see PoTा 2012; LAUNIS et al. 2014; VIGRAN et al. 2014, and references therein).

The hand specimens were analysed under a dissecting microscope and photographed with Nikon D80/Nikkor AF-S Mikro 60mm 1:2.8G ED and Nikon D300/Sigma 50mm F2.8 EX DG Macro system digital cameras; in order to enhance contrast, cross- 
polarisation and oblique lightning were used. Some specimens were analysed with an Olympus BX51 microscope under fluorescent light at the Palaeobiology Department of the Swedish Museum of Natural History, Stockholm, by CP, but no fluorescent cuticles were observed, and cuticles, if they were present, did not survive maceration by standard techniques (cf. PoTT \& MCLOUGHLIN 2009).

\section{Systematic palaeobotany}

\section{Class Cycadophyta}

Order Incerti ordinis

Family Incertae familiae

Genus Taeniopteris BRONGNIART 1828.

Diagnosis: Leaves with a simple, entire-margined lamina. Midvein rigid, extending for the entire length of the leaf. Lateral veins approximately perpendicular to the midvein, simple or forking at the base. Epidermal anatomy not known (after BRONGNIART 1828; CLEAL \& REES 2003).

Type species: Taeniopteris vittata BRONGNIART 1828; from the Middle Jurassic of Stonesfield, Oxfordshire, UK (STERNBERG 1823; MILLER 1889).

Remarks: Taeniopteris is traditionally used as a morpho-taxon for entire-margined leaves with a cycadophyte appearance, whose affinity cannot entirely be ascertained due to the lack of epidermal details (i.e. the architecture of the stomata), which are necessary for an unequivocal assignment (THOMAS \& BANCROFT 1913; POTT 2007). The use of Taeniopteris and the debate concerning its affinity and typification is addressed in the 'Discussion' section below.

Taeniopteris novomundensis C.POTT et A.LAUNIS sp. nov.

Figs. $2-5$

Records

1828 Taeniopteris vittata, pro parte. BRONGNIART, p. 263, no illustration (specimens of MERIAN).

1835 Taeniopteris vittata var. minor. MERIAN, p. 37, no illustration.

1877 Taeniopteris angustifolia SCHENK. HEER, p. 72, pl. 24, figs. 2-3, 3c, pl. 30, fig. 3e.

1966 Taeniopteris angustifolia. KRÄUSEL \& SCHAARSCHMIDT, p. 29, pl. 10, figs. 2-8. 
1983 Taeniopteris sp. VASILEVSKAYA, p. 143, pl. 6, figs. 2-4.

2010 Taeniopteris kelberi KUSTATSCHER et VAN KONIJNENBURG-VAN CITTERT 2010, pro parte. KUSTATSCHER \& VAN KoniJnenbuRG-VAN CITTERT, p. 14 (specimens of HEER, LEUTHARD and KRÄUSEL \& SCHAARSCHMIDT).

2012 Nilssoniopteris angustior (StUR ex KRASSER 1909) POTT, KRINGS et KeRP 2007, pro parte. PotT, p. 38, no illustration. Taeniopteris sp. LAUNIS et al., p. 39, fig. 4C, E-F.

Rejected records

non 1864 Taeniopteris angustifolia. SCHENK, p. 53, pl. 2, fig. 5.

non 1865 Taeniopteris angustifolia SCHENK. SCHENK in SCHÖNLEIN, p. 16, pl. 7, fig. 1, pl. 8, fig. 9.

non 1874 Danaeopsis angustifolia (SCHENK). COMPTER, p. 6, no illustration.

non 1874 Pterophyllum jaegeri var. brevifolia KURR. COMPTER, p. 6, pl. 1, fig. 1.

non 1894 Taeniopteris angustifolia SCHENK. COMPTER, p. 207, pl. 2, fig. 2.

non 1904 Taeniopteris angustifolia SCHENK (var. siliquosa LEUTHARDT). LEUTHARDT, p. 28, pl. 12, fig. 1, pl. 21, fig. 3.

non 1912 Taeniopteris angustifolia SCHENK. COMPTER, p. 82, no illustration.

non 1995 Taeniopteris angustifolia. KELBER \& HANSCH, p. 70, text-figs. 145-149, 287, 296.

non 2005 Taeniopteris angustifolia. KELBER \& NITSCH, text-fig. 8e.

See also KUSTATSCHER \& VAN KONIJNENBURG-VAN CITTERT (2010), p. 14: Taeniopteris kelberi.

Etymology: After the locality name Neuewelt (literally translated: 'new world', 'mundus novus'), where the first specimens of the new species have been obtained.

Holotype: Slight difficulties appear when tracing the specimens figured by HEER (1877) on pl. 24, figs. 2 and 3, which can be regarded as the type specimens (syntypes). KRÄUSEL \& SCHAARSCHMIDT (1966) state that the specimen in fig. 2 is lost, but the specimen in fig. 3 is still present in the collections under accession number B722/2, the illustration of which by HEER (1877), as KRÄUSEL \& SCHAARSCHMIDT (1966) state, does not entirely depict the specimen because it has been modified by the illustrator. However, when comparing the illustrations of HEER (1877) and the photographs of KRÄUSEL \& SCHAARSCHMIDT (1966), it appears to us that the specimens in pl. 10, figs. 2 and 3 of KRÄUSEL \& SCHAARSCHMIDT (1966) are those illustrated by Heer (1877) on plate 24, figs. 2 and 3, respectively. Still, it is not completely unambiguous, and, therefore, a new type is designated here. The specimen serving this best is NHMB B640, figured here on fig. 2A; we here agree with KRÄUSEL \& SCHAARSCHMIDT (1966).

Paratypes: Specimens figured by HeER (1877) on pl. 24, figs. 2 and 3, and on pl. 30, fig. 3e; and by KRÄUSEL \& SCHAARSCHMIDT (1966) on pl. 10, figs. 2-3, 5-8.

Deposition of types: Palaeontological collections of the Natural History Museum Basel (NHMB), Basel, Switzerland. 
Type locality and horizon: Neuewelt (Münchenstein), Basel-Land, Switzerland; Mergelkeuper Formation, Schilfsandstein Member, Carnian (SCHMASSMANN 1953; BITTERLI-BrUnNeR 1987; JORDAN 2008).

Material studied: NHMB B635-B640, B641/2, B722/2; VSEGEI 10979-24, 10979-25, 10979-52, 10979-65, 10979-71, 4/12163, 18/12163-20/12163; PMO 227.556A, 227.561, 227.573; LPP 24210, 24215, 24216, 24218, 15 specimens without number.

Diagnosis: Cycadophyte foliage of unknown affinity; leaves long and slender, fusiform to lanceolate; lamina robust, entire-margined, with straight margins, tapering towards extended and pointed apex and base; rachis prominent, retaining its width throughout the whole leaf; veins delicate, dense, parallel, emerging laterally from the rachis in angles of $\sim 80^{\circ}$, occasionally bifurcating close to the rachis and proceeding straight to the leaf margin; epidermal anatomy unknown.

Description: Leaves of Taeniopteris novomundensis are up to $15 \mathrm{~cm}$ long and $21 \mathrm{~mm}$ wide at their widest point (Fig. 2A-B), which is in the middle portion of the leaf. Most leaves are incomplete; some of them suggest a leaf length even up to $22-25 \mathrm{~cm}$. The leaves taper continuously towards their apex and base (Figs. 2A, C-D, 3B, 5); the apex is acutely rounded (Fig. 2A, C) and the base contracted. The entire-margined lamina was apparently very robust and is characterised by straight margins and a central, 2-4 mm wide, slightly depressed rachis (Figs. 3A, C, F, 4A-E) that proceeds into a short, 10-15 mm long petiole up to $3 \mathrm{~mm}$ wide (Figs. $3 C-D, 5)$. The rachis widens slightly when entering the petiole, but retains its width throughout the course of the whole leaf and gives off delicate, densely spaced, parallel lateral veins at angles of $75-80^{\circ}$ (Figs. 2B, 3B, E, $4 A, B, D, 5$ ), occasionally bifurcating close to the rachis and proceeding straight to the leaf margin (Figs. 3F, 4 A). No information on epidermal anatomy is available.

Occurrence: Carnian of Switzerland (Neuewelt) and Svalbard (Edgeøya and Hopen).

Remarks: Taeniopteris novomundensis is discussed below in more detail.

\section{Discussion}

\subsection{Remarks on the typification and use of Taeniopteris}

The typification of Taeniopteris is still a matter of debate and a consensus has not yet been reached. CLEAL \& REES (2003) recommended Taeniopteris vittata as the type species following MiLLER (1889), and came to the conclusion that the specimen figured by STERNBERG 
(1823, pl. 37, fig. 2; refigured by CLEAL \& REES 2003, pl. 7, fig. 1) is the "only sensible choice as lectotype" (CLEAL \& ReES 2003, p. 762). This specimen originated from the Middle Jurassic of Stonesfield, Oxfordshire, UK, and has no cuticles preserved. Therefore, it is unknown whether Taeniopteris is a cycad (comparable to Bjuvia), a bennettite (comparable to Nilssoniopteris) or even a member of the Nilssoniales (comparable to Nilssonia). CLEAL \& REES (2003) and CLEAL et al. (2006) also clarified that Taeniopteris vittata is certainly not the type of Nilssoniopteris in contrast to earlier views (e.g. FLORIN 1933; HARRIS 1969). More or less entire-margined bennettitalean leaves from the Yorkshire Jurassic that are superficially similar to Taeniopteris vittata, but where cuticles are preserved, should be more correctly referred to as Nilssoniopteris solitaria (CLEAL \& REES 2003; CLEAL et al. 2006).

It is rather questionable that the specimens published by BRONGNIART (1831, pl. 82, figs. 1-4) in the protologue of Taeniopteris vittata are conspecific with the type specimen of Taeniopteris vittata from Stonesfield. The specimen in BRONGNIART's figure 1 comes from the Aalenian of Whitby, Yorkshire, UK, and is certainly a Nilssoniopteris solitaria, whereas the specimens in figures 2 and 3 are from the Bathonian of Scarborough, Yorkshire, and could either be Nilssoniopteris major (fig. 2) or Nilssoniopteris solitaria (fig. 3) (cf. HARRIS 1969) or, less likely, a Nilssonia tenuinervis (nom. illeg., CLEAL et al. 2006) (HARRIS 1964); the fourth specimen comes from the Hettangian of Höör, Scania, Sweden, and lacks cuticle (CP, own observation) (personal communication with J.H.A. vAN KONIJNENBURG-VAN CITTERT, April 2014).

A recent proposal to conserve the name Taeniopteris with a conserved type (DOWELD 2013) also regards Taeniopteris vittata as the type but with one of the specimens published by BRONGNIART (1831, pl. 82, fig. 2) as the type specimen, which is more likely attributable to Nilssoniopteris major (based on its epidermal anatomy and the presence of brachyparacytic [=syndetocheilic] stomata). DowELD (2013) most likely overlooked STERNBERG's specimen, which certainly is a Taeniopteris, and did not consider the works of MILLER (1889) and CLEAL \& REES (2003), where the typification of Taeniopteris is assessed in detail. The author, moreover, refers to differences in epidermal anatomy between Taeniopteris and Marantoidea outlined in BORNEMANN (1856) and WEBB (2001). In the cited works, however, no information on epidermal anatomy of any of the species is given at all; and the epidermal anatomy of Taeniopteris is still unknown.

We here agree with CLEAL \& REES (2003) that the specimen of StERnBERG (1823, pl. 37, fig. 2) is the best choice as a lectotype of Taeniopteris vittata and, therefore, of Taeniopteris. 
The affinity of the genus can consequently not be clarified based on the type species/specimen, which was regarded as a leaf portion of a Scitaminea (modern Zingiberales) by STERNBERG (1823). After considerable personal discussion with J.H.A. VAN KONIJNENBURGVAN CITTERT (Leiden \& Utrecht, The Netherlands) and G. ZIJLSTRA (Utrecht, The Netherlands), we all came to the conclusion that the best and simplest option is to leave Taeniopteris as an illegitimate genus and not to support to conserve it at all. STAFLEU (1987) in an editorial note in Taxon 36, p. 648, already gave comments on the difficulties concerning the genus. However, even if the genus is illegitimate, the various species are validly published (if done according to the rules of that time) and can, therefore, be legitimate (Art. 55 in the International Code of Nomenclature for algae, fungi, and plants [Melbourne Code]; MCNEILL et al. 2012). So we can continue to use Taeniopteris as a fossil genus for leaves of a certain shape and venation, of which no cuticle is known. As soon as epidermal anatomy becomes available, the material can then be transferred to e.g. Nilssoniopteris, Nilssonia, etc. or, in the case of a fertile fern, to Danaeopsis.

\subsection{Remarks on Taeniopteris novomundensis sp. nov.}

HEER (1877) identified the Neuewelt leaves using a specimen documented by SCHENK (1864, pl. 2, fig. 5) as Taeniopteris angustifolia from Franconia. As mentioned above, this specimen has recently been identified as the holotype of Danaeopsis angustifolia (KUSTATSCHER et al., 2012), a marattialean [tree] fern characterised by large, once-pinnate fronds, whose individual pinnae resemble Taeniopteris novomundensis, but they display an entirely different venation and leaf outline (see KUSTATSCHER et al., 2012). Taeniopteris novomundensis, furthermore, represents individual single leaves that are, in our opinion, not leaflets of compound leaves. This implies that all specimens based on HEER's (1877) identification assigned to Taeniopteris angustifolia had to be reconsidered. We here include most specimens in the new species Taeniopteris novomundensis that have been identified earlier as Taeniopteris angustifolia based on HEER's report (1877).

The specimens identified by HEER (1877) as Taeniopteris angustifolia are most likely those that MERIAN (1835) collected and reported from Neuewelt as Taeniopteris vittata var. minor. From MERIAN's report (1835, p. 37), it is evident that BRONGNIART was aware of the fossils and included them in his Histoire des végétaux fossiles (BRONGNIART 1831, p. 263), but lat- 
er authors disregarded MERIAN's report. We disagree with KRÄUSEL \& SCHAARSCHMIDT (1966) that the fossils known to BRONGNIART were most likely what was later identified as Taeniopteris angustifolia var. siliquosa by LEUTHARDT (1904; =Leguminanthus siliquosus), bennettitalean microsporophylls that resemble Taeniopteris leaves folded along their rachis (see below). HeER (1877) only figured 'true' Taeniopteris angustifolia leaves and did not mention or describe the 'siliquosa' leaves at all. The 'siliquosa' leaves most likely came only later to the museum collections through the private collection of LEUTHARDT, which were acquired in 1910, and were thus unknown to Merian, Brongniart and HeEr. LeUthardt (1904, p. 28), moreover, stated that "this character [the 'folded' lamina] is present in all my specimens ... while the other leaves represent a much more slender form", which gives the impression that he regarded the 'true' specimens different. Later, he also stated that the specimens collected by MERIAN were assigned to Taeniopteris vittata by BRONGNIART (1831). The inclusion of MERIAN's or HEER's specimens in Leguminanthus siliquosus by LEUTHARDT (1904) was consequently unjustified (see also KRÄUSEL \& SCHAARSCHMIDT 1966).

Besides Neuewelt, leaves now assigned to Taeniopteris novomundensis are so far only known from different localities on Svalbard, originally reported as Taeniopteris sp. (VASILEVSKAYA, 1972, 1983; POTT 2012; LAUNIS et al. 2014). VASILEVSKAYA (1972) compared the leaves from Svalbard with specimens from Neuewelt, but refrained from assigning the Svalbard specimens to any species and left the taxonomic issue unresolved. PorT (2012) included a number of Svalbard specimens with entire-margined Taeniopteris-like foliage comprising those of VASILEVSKAYA $(1972,1983)$ in Nilssoniopteris angustior (PoTT et al. 2007b), but the new fossils found in 2011 on Hopen (LAUNIS et al. 2014) revealed that the specimens VSEGEI 10979-24, 10979-25, 10979-52, 10979-65, 10979-71, 4/12163, 18/1216320/12163 from Edgeøya and Hopen (cf. VASILEVSKAYA 1972, 1983) belong to a different species instead and thus have to be separated from the Nilssoniopteris angustior of PoTT (2012). The findings also revealed the conspecificity of the fossils from Hopen and Edgeøya with the Neuewelt specimens and prompted the here presented re-evaluation of the latter.

The material published by SCHENK in SCHÖNLEIN (1865) as Taeniopteris angustifolia has partly been assigned to Danaeopsis angustifolia by KUSTATSCHER et al. (2012). The remaining figured specimens and those reported by COMPTER (1874, 1894, 1912), KELBER \& HANSCH (1995) and KELBER \& NITSCH (2005) from the Carnian (Keuper) of Franconia, Germany, belong to a species different from Taeniopteris novomundensis as they have a different venation 
and a tapering rachis that is much wider basally (typically 8-12 $\mathrm{mm}$ wide). Those records were attributed to Taeniopteris kelberi by KUSTATSCHER \& VAN KONIJNENBURG-VAN CITTERT (2010), a species, which is very similar to Taeniopteris novomundensis, but easily recognised by its different, tapering rachis. KUSTATSCHER \& VAN KONIJNENBURG-VAN CITTERT (2010) included the Taeniopteris specimens of HEER (1877) and KRÄUSEL \& SCHAARSCHMIDT (1966) as well as the Leguminanthus siliquosus leaves of LEUTHARDT (1904) in Taeniopteris kelberi, which is, as outlined above, incorrect and consequently rejected here. Superficially similar specimens from the Upper Triassic of Franz Josef Land, Russian Federation, assigned to different Taeniopteris species by VASILEVSKAYA (1985) are better placed in Nilssoniopteris angustior (cf. PoTT et al. 2007b; POTT 2012).

A species very close if not conspecific with Taeniopteris novomundensis was reported from the Lower Cretaceous of Franz Josef Land by SVESHNIKOVA \& BUDANTSEV (1969) as Nilssoniopteris polymorpha. The similar appearance is striking, but considering these species conspecific would make it a rather long-ranging taxon, which is unreliable given the number of similar but differing species from Jurassic to Cretaceous deposits of the Northern Hemisphere (e.g. Nilssonia resoluta, N. tenuinervis, N. bluebirdii or Jacutiella amurensis; SAMYLINA 1956; HARRIS 1964; WATSON \& CUSACK 2005; POTT et al. 2014).

All specimens including those from Svalbard and Switzerland lack organic remains and information on epidermal anatomy is, consequently, unavailable. This would be evident to assign the species confidently either to Bennettitales (e.g. Nilssoniopteris), Cycadales (e.g. Bjuvia) or Nilssoniales (e.g. Nilssonia). In our opinion, a bennettitalean affinity of the species is most likely given its similarity to other Nilssoniopteris foliage types reported from Svalbard, Lunz and Neuewelt, the absence of any cycad remains (inclusive reproductive structures) from Svalbard and Neuewelt, and the different leaflet morphology of all so far known Mesozoic cycad remains. Nilssoniopteris foliage from Lunz was previously classified as Taeniopteris, which was, at that time, regarded as a genus of marattialean ferns (KRASSER 1909), but has recently been identified as bennettitalean foliage based on its epidermal anatomy (PoTT et al. 2007b). An affinity of Taeniopteris novomundensis to any fern family has been ignored per se by previous authors, but is not impossible given that Taeniopteris also included foliage specimens that were later identified as ferns.

\subsection{Remarks on Leguminanthus siliquosus}


The previous assignment of the Taeniopteris novomundensis leaves to Leguminanthus siliquosus (as Taeniopteris angustifolia var. siliquosa) by Leuthardt (1904) reveals the close resemblance of both species. Leguminanthus siliquosus organs are, however, much wider (up to $30 \mathrm{~mm}$, 'folded' form) and longer (up to $24 \mathrm{~cm}$ ) and connate at the ventral joint (KRÄUSEL \& SCHAARSCHMIDT 1966), with a much more prominent midvein (dorsal joint) and more bluntly rounded apices and broader bases. The veins of Leguminanthus siliquosus always bifurcate once close to the rachis while in Taeniopteris novomundensis, not all veins bifurcate when they enter the lamina. A closer look into their internal anatomy revealed that the previous assumption, they could just be folded Taeniopteris leaves (e.g. LEUTHARDT 1904), is unsupported. KRÄUSEL \& SCHAARSCHMIDT (1966) elucidated that Leguminanthus siliquosus is, instead, a bennettitalean microsporophyll with numerous pollen sacks attached to the 'inner' surface of the pod-like organs; it occurred in both the Neuewelt and Lunz floras. In addition, the macroscopic and epidermal anatomies of the lamina of Leguminanthus siliquosus are strikingly similar to that of Nilssoniopteris angustior from Lunz (lamina $<52$ $\mathrm{mm}$ wide, > $29 \mathrm{~cm}$ long; identical venation pattern) (PorT et al. 2007b). PorT et al. (2010), however, suggested that Nilssoniopteris angustior might be the sterile foliage of a plant bearing bennettitalean reproductive structures comprising Bennetticarpus seed cones and Haitingeria microsporophylls. This concept might have to be re-evaluated as it appears more likely that Nilssoniopteris angustior leaves and Leguminanthus siliquosus 'pods' belonged to the same parent plant. The anatomical differences make it rather unlikely that Taeniopteris novomundensis belonged to Leguminanthus siliquosus. The fertile organs of the plant bearing Taeniopteris novomundensis leaves are consequently still unknown.

It is interesting to note that Nilssoniopteris angustior has not yet been found at Neuewelt, whereas Taeniopteris novomundensis has not yet been found in the flora from Lunz, while Leguminanthus siliquosus 'pods' occurred in both floras. Both foliage types, however, co-occurred in the flora from Svalbard, together with Leguminanthus siliquosus on Kapp Lee, Kvalpynten and Kollerfjellet (POTT 2012; LAUNIS et al. 2014). In our opinion, it is more likely that Nilssoniopteris angustior was present in Neuewelt as well, but has not yet been found. Unfortunately, new material from Neuewelt will not emerge, since all localities are no longer accessible, because the area is now completely covered by concrete due to the construction of a power plant. 


\subsection{Palaeoecology and palaeogeography}

Recent re-evaluation of the Carnian flora from Svalbard (POTT 2012; LAUNIS et al. 2014) could substantiate the earlier assumed resemblance to the Neuewelt and Lunz floras from the Northern Calcareous Alps (VASILEVSKAYA 1972). A comparatively high number of taxa are shared by both floras and the Svalbard flora (cf. Poтt 2007, 2012; Poтt et al. 2008; Poтt \& KRINGS 2010; LAUNIS et al. 2014) despite their separation by more than $5000 \mathrm{~km}$ (or more than 30 degrees of latitude) already during the Carnian (Fig. 1B). At the same time, minor local differences in the composition of the floras occurred as well: cycad-like Nilssoniales (PorT et al. 2007a) have, for example, not been noted from Neuewelt or Svalbard, whereas putative pteridosperms such as Paratatarina are so far 'endemic' to Svalbard (PoTT 2012). The Carnian flora in deltaic environments in the central part of Laurasia with its northern and southern shores was consequently rather uniform and poor in diversity with minor local differences or adaptations, which led PoTT (2012) hypothesise that the floristic North Atlantic sub-province, which was well-established at the close of the Triassic (Ротा \& MCLOUGHLIN 2011), might have been developing much earlier. Ongoing collecting and concurrent analyses of the Svalbard, Lunz and Neuewelt floras are continuously producing new findings that substantiate this view (e.g. POTT et al. 2007a, 2007b; MELLER 2009; LAUNIS et al. 2014; this study; CP, own observation).

\section{Acknowledgements}

CP is much obliged to WALTER ETTER, Naturhistorisches Museum Basel, Switzerland, for providing literature and photographs of the original Taeniopteris novomundensis specimens from Neuewelt stored at the NHMB; to Johanna H.A. van KoniJnenbuRG-VAn CitTERT, Naturalis Biodiversity Centre, Leiden, and Laboratory of Palaeobotany and Palynology (LPP), University Utrecht, Utrecht, The Netherlands, and GEA ZIJLSTRA, LPP, University Utrecht, Utrecht, The Netherlands, for the discussion of the typification of Taeniopteris and Taeniopteris novomundensis. ROMAIN THOMAS from the Musée nationale d'Histoire naturelle, Paris, France, is thanked for providing images and a sample for cuticular analysis of the original BRONGNIART specimens. CP acknowledges financial support from the Swedish Research Council (Vetenskapsrådet), Stockholm, Sweden; the Friends of the Swedish Museum of Natural History (Riksmusei Vänner), Stockholm, Sweden, supported the journey to St. Petersburg with a travel grant. AL would like to thank Atle Mørk, SINTEF, Trondheim, Norway, for the possibility to participate in the geological excursion to Hopen in August 2011, during which he collected the fossils. 


\section{References}

BitTERLI-BRUNNER, P. (1987): Geologischer Führer der Region Basel. - 232 pp.; Basel (Birkhäuser).

BORNEMANN, J. G. (1856): Über organische Reste der Lettenkohlengruppe Thüringens. - 85 pp.; Leipzig (Engelmann).

Brongniart, A. (1828): Prodrome d'une histoire des végétaux fossils. - VIII+223 pp.; Paris (Levrault).

BRONGNIART, A. (1828-1837): Histoire des végétaux fossiles ou recherches botaniques et géologiques sur les végétaux renfermés dans les divers couches du globe. - Vol. I: XII+488 pp., Vol. II: 472 pp., Atlas: 166+430 pl.; Paris (G. Dufour et Ed. d'Ocagne/ Crochard et Compagnie).

Cleat, C. J. \& ReES, P. M. (2003): The Middle Jurassic flora from Stonesfield, Oxfordshire, UK. - Palaeontology, 46: 739-801.

CleAL, C. J., ReES, P. M., ZIJLSTRA, G. \& CANTRILL, D. J. (2006): A clarification of the type of Nilssoniopteris Nathorst (fossil Gymnospermophyta, Bennettitales). - Taxon, 55: 219-222.

COMPTER, G. (1874): Ein Beitrag zur fossilen Keuperflora. - Nova Acta der kasierlichen leopoldinischcarolinischen deutschen Akademie der Naturforscher, 37: 13-10.

COMPTER, G. (1894): Die fossile Flora des unteren Keupers von Ostthüringen. - Zeitschrift für Naturwissenschaften, 67: 205-230.

COMPTER, G. (1912): Revision der fossilen Keuperflora Ostthüringens. - Zeitschrift für Naturwissenschaften, 83: 81-116.

DowelD, A. B. (2013): (2249-2250) Proposals to conserve the names Taeniopteris with a conserved type and T. vittata with a conserved type (fossil Gymnospermae: Cycadeoideopsida). - Taxon, 62: 1348-1349

FLORIN, R. (1933): Zur Kenntnis der Spaltöffnungsapparate der Bennettitales. - Kungliga Svenska Vetenskapsakademiens Handlingar, Tredje Serien, 12: 11-31.

HARRIS, T. M. (1964): The Yorkshire Jurassic flora - II. Caytoniales, Cycadales \& pteridosperms. - VIII+191 pp.; London (Trustees of the British Museum [Natural History]).

HARRIS, T. M. (1969): The Yorkshire Jurassic flora - III. Bennettitales. - VI+186 pp.; London (Trustees of the British Museum [Natural History]).

HEER, O. (1877): Flora fossilis Helvetiae - Die vorweltliche Flora der Schweiz. - VIII+182 pp.; Zürich (J. Wurster \& Comp.).

JORDAN, P. (2008): Basin evolution: Switzerland. - In: MCCANN, T. (Ed.): The geology of central Europe, Volume 2: Mesozoic and Cenozoic, 785-788; London (Geological Society of London).

KELBER, K.-P. \& HANSCH, W. (1995): Keuperpflanzen - Die Enträtselung einer über 200 Millionen Jahre alten Flora. - Museo, 11: 1-157.

KELBER, K.-P. \& NITSCH, E. (2005): Paläoflora und Ablagerungsräume im unterfränkischen Keuper. - Jahresberichte und Mitteilungen des oberrheinischen geologischen Vereins, 87: 217-253. 
KRASSER, F. (1909): Die Diagnosen der von Dionysius Stur in der obertriadischen Flora der Lunzerschichten als Marattiaceenarten unterschiedenen Farne. - Sitzungsberichte der kaiserlichen Akademie der Wissenschaften Wien, Abt. 1, 118: 13-43.

KRÄUSEL, R. \& SCHAARSCHMIDT, F. (1966): Die Keuperflora von Neuewelt bei Basel - IV. Pterophyllen und Taeniopteriden. - Schweizer paläontologische Abhandlungen, 84: 3-44.

Kustatscher, E., Kelber, K.-P. \& Van Konijnenburg-van Cittert, J. H. A. (2012): Danaeopsis Heer ex Schimper 1869 and its European Triassic species. - Review of Palaeobotany and Palynology, 183: 32-49.

Kustatscher, E. \& VAN KoniJnenburg-VAn CitTERT, J. H. A. (2010): Seedferns and cycadophytes from the Triassic flora of Thale, Germany. - Neues Jahrbuch für Geologie und Paläontologie, Abhandlungen, 258: 195217.

Launis, A., PotT, C. \& MørK, A. (2014): A glimpse into the Carnian: Late Triassic plant fossils from Hopen, Svalbard. - Norwegian Petroleum Directorate Bulletin, 11: 35-42.

LeUTHARDT, F. (1904): Die Keuperflora von Neuewelt bei Basel - II. Teil Kryptogamen. Abhandlungen der schweizer paläontologischen Gesellschaft, 31: 25-48.

McNeill, J., Barrie, F. R., Buck, W. R., Demoulin, V., Greuter, W., Hawksworth, D. L., Herendeen, P. S., KNapp, S., Marhold, K., Prado, J., Prud'homme van Reine, W. F., Smith, G. F., Wiersema, J. H. \& Turland, N. J. (2012): International Code of Nomenclature for algae, fungi, and plants (Melbourne Code) adopted by the Eighteenth International Botanical Congress Melbourne, Australia, July 2011. Regnum Vegetabile 154. - 240 pp.; Königstein (Koeltz Scientific Books).

MELLER, B. (2009): Neue paläobotanische Funde aus der Lunz Formation von Lunz-am-See (Karnium, Obertrias, Österreich). - Abstracts of the 79. Jahrestagung der paläontologischen Gesellschaft in Bonn, Terra Nostra 2009/3: 80-81.

MERIAN, P. (1835): Über die fossile Flora der Keuperformation in den Umgebungen von Basel. Verhandlungen der naturforschenden Gesellschaft zu Basel, 1: 36-38.

MILLER, S. A. (1889): North American geology and palaeontology. - 793 pp.; Cincinnati, OH (Western Methodist Book Concern).

PoтT, C. (2007): Cuticular analysis of gymnosperm foliage from the Carnian (Upper Triassic) of Lunz, Lower Austria. - IV+274 pp.; Münster (Westfälische Wilhelms-Universität, Fachbereich Geowissenschaften).

PotT, C. (2012): The Triassic flora of Svalbard. - Acta Palaeontologica Polonica, 59: DOI: 10.4202/app.2012.0090.

PotT, C., GuHL, M. \& LehmanN, J. (2014): The Early Cretaceous flora from the Wealden facies at Duingen, Germany. - Review of Palaeobotany and Palynology, 201: 75-105.

POTT, C., KERP, H. \& KRINGS, M. (2007a): Morphology and epidermal anatomy of Nilssonia (cycadalean foliage) from the Upper Triassic of Lunz (Lower Austria). - Review of Palaeobotany and Palynology, 143: 197217.

PotT, C. \& KRINGS, M. (2010): Gymnosperm foliage from the Upper Triassic of Lunz, Lower Austria: An annotated checklist and identification key. - Geo.Alp, 7: 19-38.

POTT, C., KRINGS, M. \& KERP, H. (2007b): First record of Nilssoniopteris (Gymnospermophyta, Bennettitales) from the Carnian (Upper Triassic) of Lunz, Lower Austria. - Palaeontology, 50: 1299-1318. 
PotT, C., KRINGS, M. \& KeRP, H. (2008): The Carnian (Late Triassic) flora from Lunz in Lower Austria: Palaeoecological considerations. - Palaeoworld, 17: 172-182.

POTT, C., KRINGS, M., KERP, H. \& FRIIS, E. M. (2010): Reconstruction of a bennettitalean flower from the Carnian (Upper Triassic) of Lunz, Lower Austria. - Review of Palaeobotany and Palynology, 159: 94-111.

PotT, C. \& MCLoughlin, S. (2009): Bennettitalean foliage from the Rhaetian-Bajocian (latest Triassic-Middle Jurassic) floras of Scania, southern Sweden. - Review of Palaeobotany and Palynology, 158: 117-166.

SAMYLINA, V. A. (1956): New cycadophytes in Mesozoic deposits of River Aldan. - Botaničeskij Žurnal, 41: 13341339. [In Russian].

SCHENK, A. (1864): Beiträge zur Flora des Keupers und der rhätischen Formation. - Berichte der naturforschenden Gesellschaft zu Bamberg, 7: 1-91.

SCHMASSMANN, H. J. (1953): Das Keuper-Profil von Neue Welt. - Tätigkeitsberichte der naturforschenden Gesellschaft Baselland, 19: 129-153.

SCHÖNLEIN, J. L. (1865): Abbildungen von fossilen Pflanzen aus dem Keuper Frankens (A. SCHENK, ed.). - 22 pp.; Wiesbaden (C. W. Kreidel).

StAFLEU, F. A. (1987): Nomenclatural editorial note to proposal (879). - Taxon, 36: 648.

STERNBERG, K. M. G. VON (1820-1838): Versuch einer geognostisch-botanischen Darstellung der Flora der Vorwelt. - Vol. I, 144+XLII; Vol. II, 180 pp.; Leipzig (Fleischer), Regensburg (Brenck), Prag (Spurny).

SVESHNIKOVA, I. N. \& BUDANTSEV, L. J. (1969): Iskopaemye flory arktiki - 1. Paleozojskie i mezozojskie flory Zapadnogo Špicbergena, Zemli Franca-losifa i ostrova Novaâ Sibir'. - 106 pp.; Leningrad (Nauka). [In Russian].

THOMAS, H. H. \& BANCROFT, N. (1913): On the cuticles of some recent and fossil cycadean fronds. - Transactions of the Linnean Society of London: Botany, 8: 155-204.

VASILEVSKAYA, N. D. (1972): The Late Triassic flora of Svalbard. In: SOKOLOVA, V. N. \& VASILEVSKAYA, N. D. (Eds.): Mezozojskie otloženiâ Sval'barda, 27-63; Leningrad (NIIGA). [In Russian].

VASILEVSKAYA, N. D. (1983): Late Triassic plants from the Island of Hopen (Svalbard). In: VASILEVSKAYA, N.D. (Ed.): Geologiâ Špicbergena, 142-149; Leningrad (Ministerstvo geologii SSSR, PGO "Sevmorgeologia"). [In Russian].

VASILEVSKAYA, N. D. (1985): Triassic flora of Franz-Joseph-Land and Novaya Zemlya. In: VASILEVSKAYA, N. D. (Ed.): Stratigrafiâ i paleontologiâ mezozojskih osadočnyh bassejnov Severa SSSR, 34-45; Leningrad (Ministerstvo geologii SSSR, PGO “Sevmorgeologia”). [In Russian].

Vigran, J. O., MANGerud, G., Mørk, A., Worsley, D. \& Hochuli, P. A. (2014): Palynology and geology of the Triassic succession of Svalbard and the Barents Sea. Geological Survey of Norway Special Publication, 14: 1269.

WATSON, J. \& CUSACK, H. A. (2005): Cycadales of the English Wealden. - Monograph of the Palaeontographical Society, 622 (as part of Volume 158 for 2004): 1-189.

WEBB, J. A. (2001): A new marattialean fern from the Middle Triassic of eastern Australia. - The Proceedings of the Linnean Society of New South Wales, 123: 215-223.

\section{Addresses of the authors:}


ChRISTIAN POT, Swedish Museum of Natural History, Department of Palaeobiology, Box 50007, SE-104 05 Stockholm, Sweden; e-mail: christian.pott@nrm.se;

AHTI LAUNIS, Department of Biological and Environmental Sciences \& Botanical Museum, P.O. Box 7, FI-00014 University of Helsinki, Finland. 


\section{Figure captions}

Fig. 1. A - Map of northern Europe depicting the present day locations of the Neuewelt, Edgeøya and Hopen fossil localities. B - Map of the same area during the Late Triassic (220 mya) with the contemporary locations of the Neuewelt and Svalbard floras. Palaeomap based on reconstructions by Ron Blakey, Colorado Plateau Geosystems, Inc., Flagstaff, AZ, USA. Scale bars - 500 km.

Fig. 2. Taeniopteris novomundensis sp. nov. from the Carnian of Neuewelt, Münchenstein, Basel-Land, Switzerland. A - Lectotype, depicting the upper portion of a leaf; note the pointed apex; specimen NHMB B640. B - Close-up of the lower portion of the specimen in A, depicting details of the venation. $\mathbf{C}$-Another leaf on the lectotype specimen; note the pointed apex, the tapering leaf lamina and the venation. D - Upper portion of a leaf; specimen NHMB B636. Scale bars $-1 \mathrm{~cm}$.

Fig. 3. Taeniopteris novomundensis sp. nov. from the Carnian of Kapp Lee, Edgeøya, and Kollerfjellet, Hopen, Svalbard. A - Well-preserved middle portion of a leaf; specimen PMO 227.573. B - Almost complete leaf; note the lamina tapering towards base and apex; specimen PMO 227.556A. C - Complete leaf, of which the apex is bent down into the rock matrix; note the central rachis keeping its width throughout the course of the leaf; specimen VSEGEI 4/12163. D - Almost entire leaf; note the petiole; specimen VSEGEI 10797-52. E - Upper portion of a leaf; note the rachis and the secondary veins; specimen VSEGEI 10797-25. F - Close-up of the middle portion of the specimen in A depicting the venation in detail. Scale bars $-1 \mathrm{~cm}$.

Fig. 4. Taeniopteris novomundensis sp. nov. from the Carnian of Kvalpynten, Edgeøya, Svalbard. Wellpreserved middle portions of different leaves. A - Specimen LPP 24210. B - Specimen LPP 24215. C Specimen LPP 24216. D - Specimen LPP 24216. E - Specimen LPP 24218. Scale bars - 1 cm.

Fig. 5. Restoration of an entire leaf of Taeniopteris novomundensis sp. nov. based on different specimens from Neuewelt, Edgeøya and Hopen. Scale bar $-1 \mathrm{~cm}$. 

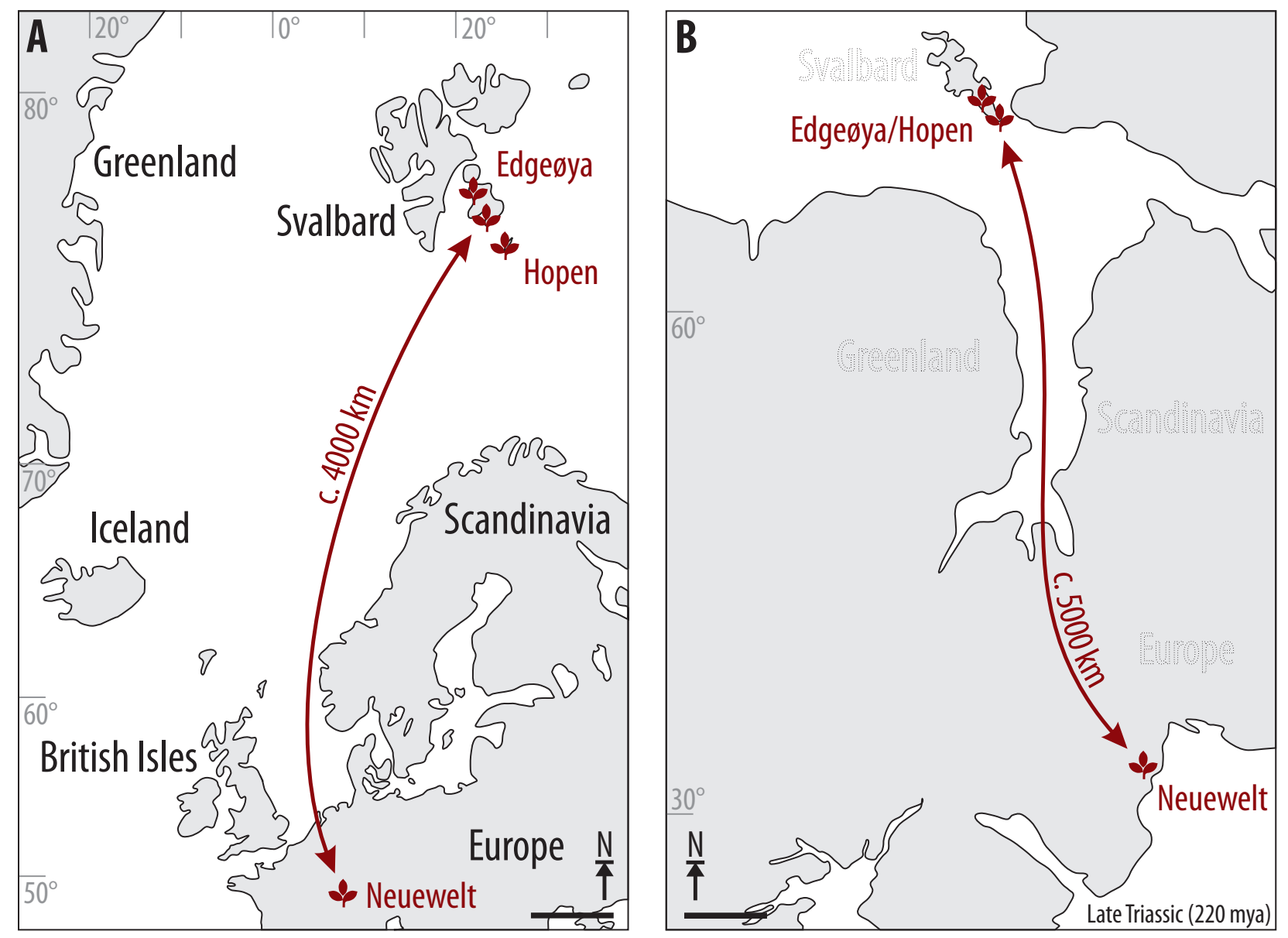


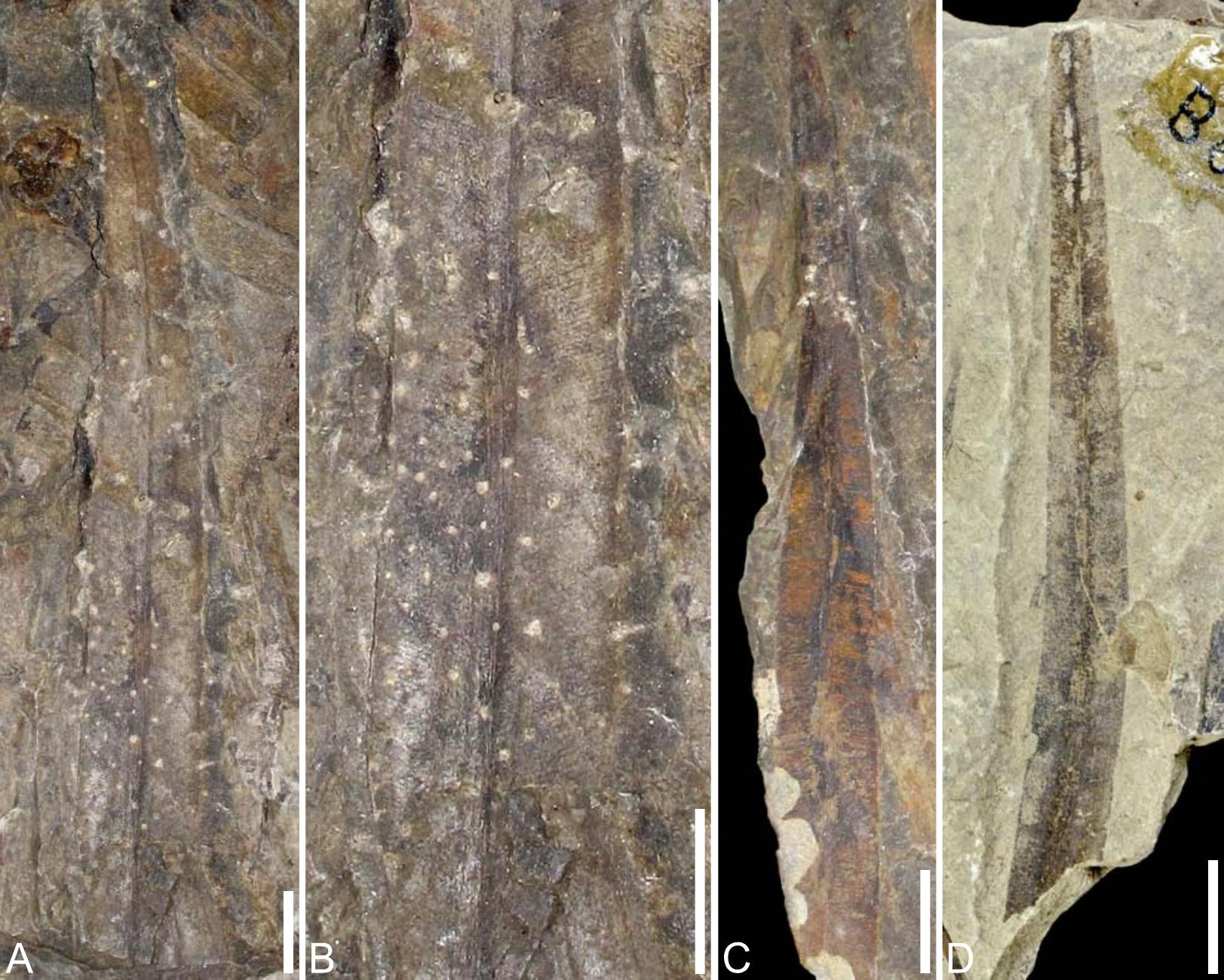




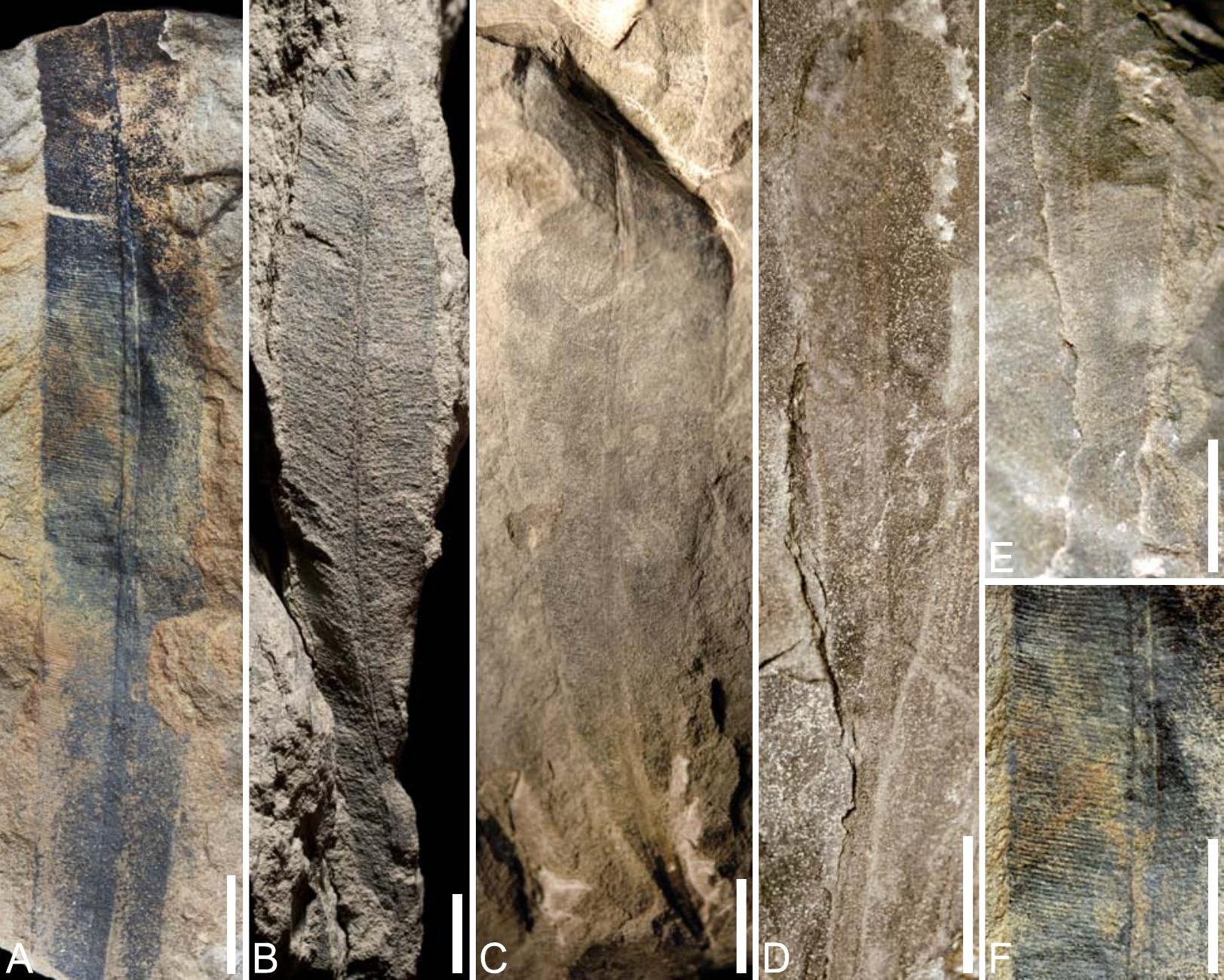




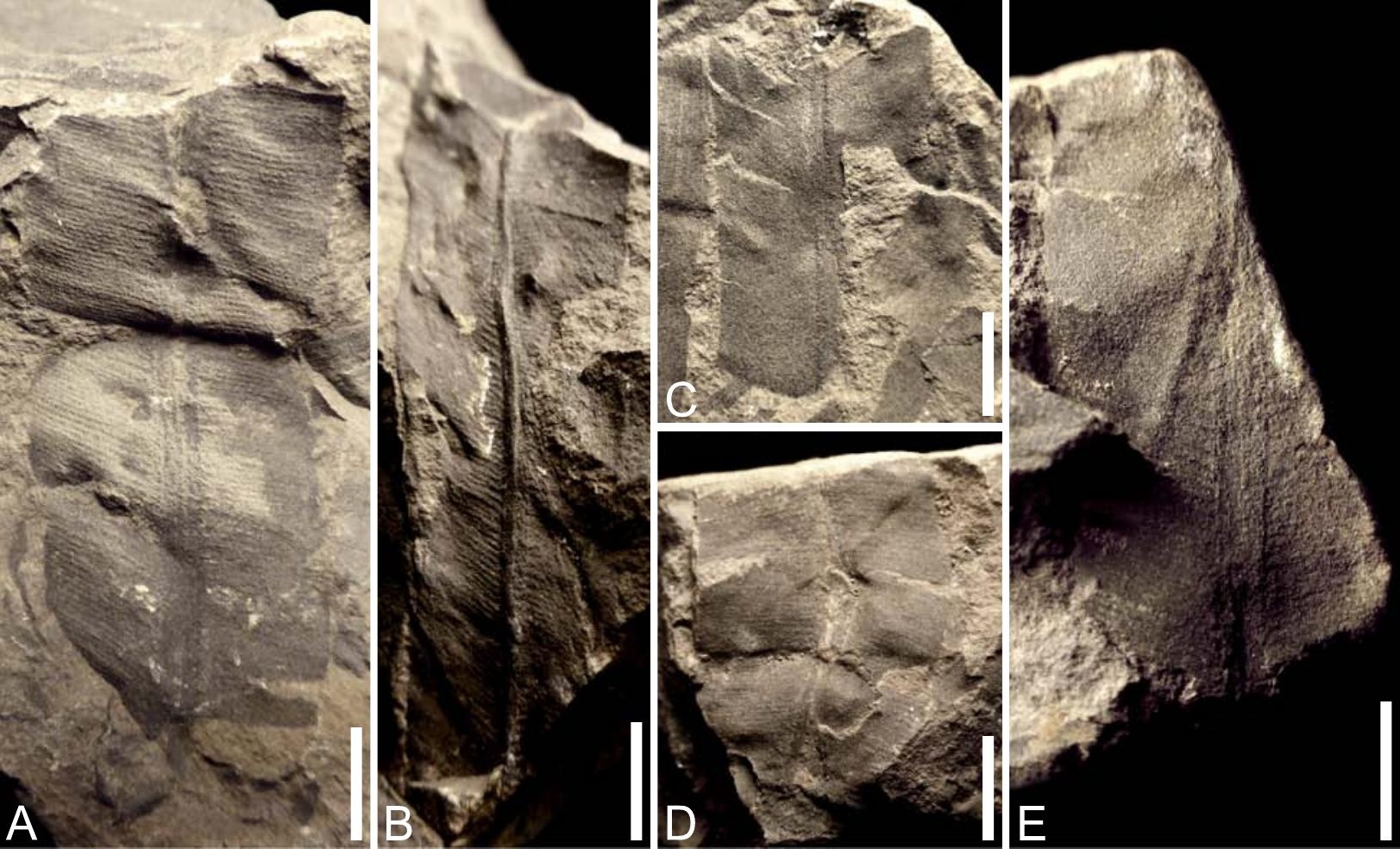


